\title{
Effect of Halo Priming, Osmo Priming and Hydro Priming on Fresh and Accelerated Aged Seeds of Baby Corn (Zea mays L.) on Germination, Seedling Dry Weight, Seedling Length
}

\author{
Akash Bhargaw $^{1 *}$, Akanksha1, Dnyaneshwar Arjun Madane ${ }^{2}$ and Priyamvada Chauhan ${ }^{2}$ \\ ${ }^{1}$ Department of Agronomy, School of Agriculture, ${ }^{2}$ Department of Agronomy, Lovely \\ Professional, University, Phagwara, 144411, Punjab, India \\ *Corresponding author
}

\section{Keywords \\ Vigour Index, Priming, Cell membrane, $\mathrm{CaCl}_{2}$, $\mathrm{KNO}_{3}$ \\ Article Info \\ Accepted: \\ 12 April 2019 \\ Available Online: \\ 10 May 2019}

\section{A B S T R A C T}

\section{Introduction}

Baby corn is a nutritive and delicious product continuously gaining popularity in big cities and towns. Because of its sweet and nutritive values it is highly demanded in hotels and restaurants. It consist of carbohydrates, vitamins, proteins, fat and minerals in sufficient, and in digestible matter. Baby corn is a rich source of phosphorus $(82 \mathrm{mg} / 100 \mathrm{~g}$ of portion in compare to other common vegetable only contain 21 to $57 \mathrm{mg}$ of
This experiment was laid down in Post Graduate Laboratory, Department of Agronomy Lovely Professional, University, Phagwara, Punjab which is situated at Latitude at 31.253 $\mathrm{N}$ and Longitude at 75.703E at the altitude of $240.0 \mathrm{~m}$ above the sea level. To check the effect of halo priming, osmo priming, and hydro priming on the fresh and accelerated aged baby corn seeds. Different dose of priming solution with different time duration was tested. $\mathrm{T}_{0^{-}}$Unprimed (control) $\mathrm{T}_{1}$ Distil Water 12 hours, $\mathrm{T}_{2}$ Distil Water 24 hours, hydro priming, $\mathrm{T}_{3} \mathrm{KNO}_{3} 1 \% 12$ hours, $\mathrm{T}_{4} \mathrm{KNO}_{3} 1 \% 24$ hours, osmo priming, $\mathrm{T}_{5} \mathrm{CaCl}_{2} 1 \% 12$ hours, $\mathrm{T}_{6} \mathrm{CaCl}_{2} 1 \% 24$ hours, halo priming. It was observed that all primed seeds showed significant difference among each other in both seeds slot (fresh and aged) in term of germination percent, seedling length, seedling dry weight, and vigour index I II. It was observed that seeds treated with hydro priming for 24 hours had showed maximum values in all the above parameter in both seed slots. 
Baby corn has been gaining popularity in countries like US, EU, China, Japan and south East Asia. Developing countries like Zambia, South Africa and Vietnam has also started their cultivation. Today China and Thailand is the most producers of baby corn as well as top in consuming. Besides being domestically consumed it has also a huge potential of export. So as a cash crop it can be grown in India by small farmers to gain income between two seasons as well as its byproduct can be also used as fodder crop which can help in our dairy farming. By huge market possibility farmers of Meghalaya, western Uttar Pradesh, Karnataka and Bihar has started cultivating baby corn (Ramachandrappa et al., 2004).

Some Common food recipes made by using Baby corn

Baby corn soup with Manchurian.

Baby corn pizza

Moroccan Couscous plate of mixed greens with Baby Corn

Baby Corn fry with Carrots and mushroom

\section{Materials and Methods}

This experiment was laid down in Post Graduate Laboratory, Department of Agronomy, Lovely Professional, University, Phagwara, Punjab which is situated at Latitude at $31.253 \mathrm{~N}$ and Longitude at $75.703 \mathrm{E}$ at the altitude of $240.0 \mathrm{~m}$ above the sea level. To check the effect of halo priming, osmo priming, and hydro priming on the fresh and accelerated aged baby corn seeds. Different dose of priming solution with different time duration was tested. $\mathrm{T}_{0^{-}}$ Unprimed (control) $\mathrm{T}_{1}$ Distil Water 12 hours, $\mathrm{T}_{2}$ Distil Water 24 hours, hydro priming, $\mathrm{T}_{3}$ $\mathrm{KNO}_{3} \quad 1 \% 12$ hours, $\mathrm{T}_{4} \mathrm{KNO}_{3} \quad 1 \% 24$ hours, osmo priming, $\mathrm{T}_{5} \mathrm{CaCl}_{2} 1 \% 12$ hours, $\mathrm{T}_{6}$ $\mathrm{CaCl}_{2} \quad 1 \% 24$ hours, halo priming. Total 1.4 $\mathrm{kg}$ of baby corn seed were taken each was further divided into 100 grams of packet total 14 packet were created.

\section{Accelerated ageing}

The Baby corn seeds were accelerated aged from (Delouche and Baskin, 1973) method. For accelerated ageing seed sample were placed on monolayer wire gauze in a controlled humidity .Chamber maintained or adjusted at $400 \mathrm{C} \pm 10 \mathrm{C}$ and 100 percent relative humidity. The humidity in chamber was maintained for 24 hours in all three replications for analyses. All the observations on seed quality and biochemical parameters recorded were the average of three replications.

\section{Seed priming method}

For $\mathrm{T}_{0}$ (control) 100 grams of seed were taken and without any treatment it was stored in air tight zip bags. For $\mathrm{T}_{1}$ (Hydro priming) 100 grams of seed were soaked in $200 \mathrm{ml}$ of double distil water in $500 \mathrm{ml}$ of glass beaker for 12 hours. For $\mathrm{T}_{2}$ (Hydro priming) 100 grams of seed were taken and soaked in 200 $\mathrm{ml}$ of double distil water for 24 hours (Ahammad, 2014). For $\mathrm{T}_{3}$ (osmo priming) for osmo priming $\mathrm{KNO}_{3}$ was used as a solvent. 1 $\%$ of $\mathrm{KNO}_{3}$ solution was prepared. 2 gram of $\mathrm{KNO}_{3}$ was taken in $200 \mathrm{ml}$ of distil water in a beaker. Seed of 100 grams was soaked in that solution for 12 hours. For $\mathrm{T}_{4}$ (osmo priming) same solution and same seed weight used in $\mathrm{T}_{3}$ treatment was used but the timing for soaking of seed was increased for 24 hours (Kumari et al., 2017 and Soleimanzadeh, 2013). For $T_{5}$ (Halo priming) for halo priming $\mathrm{CaCl} 2$ was used as solvent. $1 \%$ of solution was to be made. For preparing $1 \%$ of solution 2 gram of $\mathrm{CaCl}_{2}$ was taken and $200 \mathrm{ml}$ of distil water was used. 100 grams of seed was soaked for 12 hours. For $\mathrm{T}_{6}$ (Halo priming) same solution and same quantity of seed was soaked for $24 \mathrm{hrs}$ (Debnath et al., 2017). 


\section{Germination test}

Stander germination test was conducted by paper germination test method. Before using this paper it was to be kept for overnight soaked in water. Next day on one butter paper two germination paper well soaked in water is to be kept. On that paper 100 seeds were kept in proper rows and Coolum and then it is covered with one more paper soaked in water. After this it is covered with butter paper and is folded in round bundle while folding it must be kept in mind that seeds position in paper should not be disturbed. Butter paper is used here to cover the paper roll by both sides so that to minimize water loss throw evaporation. Three replication of each treatment was maintained. Then this all paper folds are kept in a tray with 2, 3 inch of water in tray. And this tray along with paper fold should be kept in germination chamber. Temperature of germination chamber should be kept between $23{ }^{\circ} \mathrm{C}$ to $27 \mathrm{C}$ but ideal temperature for baby corn seed germination is 25C. So germination chamber temperature was kept at $25 \mathrm{C}$ for 12 days.

\section{Results and Discussion}

Significant variation was observed between fresh and aged seed slot and within different treatment of priming which is mention in table 1 .

According to table the mean germination percent of fresh seed was calculated $73.9 \%$ in which highest germination percent was observed in $\mathrm{T}_{6}$ in hydro priming for 24 hours followed by other hydro primed treatment for 12 hours and lowest germination was observed in $\mathrm{T}_{0}$ in control. Mean germination for aged seed was calculated $68.9 \%$ in which $\mathrm{T}_{6}$ hydro priming for 24 hours followed by hydro primed treatment 12 hours and lowest was in $\mathrm{T}_{0}$ Soleimanzadeh (2013).
This difference in germination percent between fresh and aged seed may be due to the embryo injury of aged seed and metabolic slowdown. Second possible reason may be due to slow mobilization of soluble molecules of sugar which ultimately delay the germination process (Mc Donald, 1999 and Powell et al., 2000).

The mean followed by different letters are significantly different at $p<0.01$ according to tukey LSD for separation of mean

Significant variation was obtained between the fresh and aged seed slots as well as difference in value was also obtain within different type of priming methods as mention in table 2 .

The mean value of fresh seed seedling length was obtaining $9.11 \mathrm{~cm}$ and highest seedling length was observed in $\mathrm{T}_{2}$ hydro priming 24 hours and lowest length was observed in $\mathrm{T}_{0}$ control. On other hand mean seedling length for aged seeds was calculated $8.1 \mathrm{~cm}$ in which hydro priming for 24 hours showed maximum seedling length and minimum was obtain in control. Present results are justified by Ahammad (2014).

Better growth in hydro priming could be due to better absorb of water by seeds which further help seeds in imbibition process followed by other steps needed for germination. Reduce in length in aged seeds may be due to slow physiological reaction in cell membrane occurring due to reduce in soluble sugar molecule. Second possible reason for reduce in seedling length may be due to damage in embryo and due to leakage.

Mean seedling dry weight for fresh seed slot was calculated $151.4 \mathrm{mg}$ in which highest dry weight was obtain in hydro primed seed for 24 hours and lowest was control. And mean seedling dry weight in aged seed was 
calculated $134.6 \mathrm{mg}$ in which again hydro primed seeds for 24 hours had showed maximum results and lowest was obtain in control Rahman et al., (2014).

Improvement in seedling length can be partially related to dry matter contain as it is not compulsory that if long seedling growth will have more dry weight. But in most of the case length can effect directly to weight of seedling. In present study primed methods had helped the seeds to repair and nourish the cell membrane, complete first two steps of seed germination. As from data mention in table 1 and 2 it is clear that although mean value of aged seed is less than fresh seed in germination, seedling length and seedling dry weight but still some primed aged seeds had showed better results in compare to control of fresh seed slot (Hussaini et al., 1988 and Ramamoorthy et al., 1989).

Table.1 Paper germination test

\begin{tabular}{|l|l|l|}
\hline Treatment & Fresh seed & Aged Seed \\
\hline $\mathbf{T}_{\mathbf{0}}$ & $69.3^{\mathrm{a}} \pm 2.7$ & $61.0^{\mathrm{c}} \pm 0.5$ \\
\hline $\mathbf{T}_{\mathbf{1}}$ & $80.0^{\mathrm{a}} \pm 2.0$ & $73.6^{\mathrm{ab}} \pm 0.8$ \\
\hline $\mathbf{T}_{\mathbf{2}}$ & $81.3^{\mathrm{a}} \pm 1.4$ & $75.0^{\mathrm{a}} \pm 1.4$ \\
\hline $\mathbf{T}_{\mathbf{3}}$ & $70.0^{\mathrm{a}} \pm 1.7$ & $66.3^{\mathrm{bc}} \pm 1.7$ \\
\hline $\mathbf{T}_{\mathbf{4}}$ & $72.3^{\mathrm{a}} \pm 0.8$ & $68.0^{\mathrm{abc}} \pm 0.8$ \\
\hline $\mathbf{T}_{\mathbf{5}}$ & $70.0^{\mathrm{a}} \pm 2.0$ & $68.0^{\mathrm{abc}} \pm 1.0$ \\
\hline $\mathbf{T}_{\mathbf{6}}$ & $74.0^{\mathrm{a}} \pm 2.0$ & $70.3^{\mathrm{ab}} \pm 1.7$ \\
\hline
\end{tabular}

Table.2 Seedling length and seedling weight

\begin{tabular}{|l|l|l|l|l|}
\hline & \multicolumn{2}{|l|}{ seedling length (cm) } & \multicolumn{2}{l|}{ seedling dry weight (mg) } \\
\hline Treatment & Fresh seeds & Aged seeds & Fresh seeds & Aged seeds \\
\hline $\mathbf{T}_{\mathbf{0}}$ & $8.85^{\mathrm{c}} \pm 0.01$ & $7.84^{\mathrm{b}} \pm 0.04$ & $134.3^{\mathrm{b}} \pm 10.7$ & $122.0^{\mathrm{b}} \pm 2.00$ \\
\hline $\mathbf{T}_{\mathbf{1}}$ & $9.30^{\mathrm{a}} \pm 0.02$ & $8.25^{\mathrm{ab}} \pm 0.05$ & $159.3^{\mathrm{a}} \pm 4.09$ & $142.6^{\mathrm{ab}} \pm 4.84$ \\
\hline $\mathbf{T}_{\mathbf{2}}$ & $9.39^{\mathrm{a}} \pm 0.01$ & $8.48^{\mathrm{a}} \pm 0.22$ & $160.0^{\mathrm{a}} \pm 4.04$ & $143.6^{\mathrm{a}} \pm 1.76$ \\
\hline $\mathbf{T}_{\mathbf{3}}$ & $9.03^{\mathrm{b}} \pm 0.02$ & $8.01^{\mathrm{ab}} \pm 0.01$ & $147.0^{\mathrm{a}} \pm 2.30$ & $130.3^{\mathrm{ab}} \pm 4.80$ \\
\hline $\mathbf{T}_{\mathbf{4}}$ & $9.12^{\mathrm{b}} \pm 0.01$ & $8.06^{\mathrm{ab}} \pm 0.00$ & $155.3^{\mathrm{a}} \pm 1.33$ & $138.6^{\mathrm{ab}} \pm 4.17$ \\
\hline $\mathbf{T}_{\mathbf{5}}$ & $9.04^{\mathrm{b}} \pm 0.01$ & $8.04^{\mathrm{a}} \pm 0.02$ & $148.6^{\mathrm{a}} \pm 3.71$ & $132.0^{\mathrm{ab}} \pm 4.00$ \\
\hline $\mathbf{T}_{\mathbf{6}}$ & $9.08^{\mathrm{b}} \pm 0.00$ & $8.06^{\mathrm{ab}} \pm 0.00$ & $152.6^{\mathrm{a}} \pm 3.92$ & $133.3^{\mathrm{ab}} \pm 1.66$ \\
\hline
\end{tabular}

The mean followed by different letters are significantly different at $p<0.01$ according to tukey LSD for separation of mean.

From above experiment it can be concluded that priming technique is effective method to improve germination percent, promote dormancy seeds, and improve seedling length and seedling dry weight mortally priming is very effective in aged seed as aged seed start 
losing its qualitative character after some time. Among other priming methods like halo priming and osmo priming hydro priming for 24 hours had showed better results in both seed slot.

\section{References}

Almeida, I. P. C., Silva, P. S., Negreins, M. Z. and Barbosa, Z. 2005. Baby corn, green ear and grain yield of corn cultivation. Horticultura Brasileira, Brasilia 23: 960-964.

A.O.A. C. 1984. Official methods of analysis. 14th ed. Association ofofficial analytical chemists, Arlington, VA, VSA, p. 415

Balasubramanian, V. and J.E. Hill, 2002. Direct seeding of rice in Asia: Emerging issues and strategic research needs for 21st century. In: Pandey, S., M. Mortimer, L. Wade, T.P. Tuong, K. Lopes and B. Hardy (eds.), Direct Seeding: Research Strategies and Opportunities, pp: 15-39. International Rice Research Institute (IRRI), Manila Philippines

Barlow, E.W.R and Haigh, A.M. 1987. Effect of seed priming on the emergence, growth and yield of UC 82B tomatoes in the field. Acta Horticulturae. 200: 153-64.

Bino, R.J., Devries, J.N., Kraak, H.L., VanPijlen, J.G 1992. Flow cytometric determination of nuclear replication stages in tomato seeds during priming and germination. Annals of Botany. 69: 231-236.

Black, C. A. 1973. Laboratory methods of soil investigation and soil fertility. Department of Agronomy, Iowa State College, Iowa, U.S.A, 3rd edition

Chandrasenan, N.V. 1996. Effect of provenance on seed quality and halogenations treat ment to control the seed deterioration. M.Sc. (Ag.) Thesis.
Tamil Nadu Agricultural University, Coimbatore, India

Farahbakhsh H. Germination and seedling growth in primed and primed seeds of fennel as affected by reduced water potential induced by $\mathrm{NaCl}$. Inter Research Journal of Applied Basic Sciences. 2012; 3:737-44

Farooq M, Basra SMA, Wahid A. Priming of field sown rice seed enhances germination, seedling established, allometry and yield. Plant Growth Regulator. 2006; 49:285-294

Farooq M, Basra SMA, Wahid A. Priming of field sown rice seed enhances germination, seedling established, allometry and yield. Plant Growth Regulator. 2006; 49:285-294.

Gaur, B. L., Mansian, P. R. and Gupta, D. C. 1992. Effect of nitrogen level and their splits on yield of winter maize (Zea mays L.). Indian Journal of Agronomy 37: 816-817.

Ghassemi-Golezani K, Aliloo AA, Valizadeh M, Moghaddam M. Effects of Hydro and Osmo-Priming on Seed Germination and Field Emergence of Lentil (Lens culinaris Medik.). Not Bot Hort AgrobotCluj. 2008; 36:29-33

Ghassemi-Golezani, K., Chadrdoozjeddi, A., Nasrullahzadeh, S and Moghaddam, M. 2010. Influence of hydro-priming duration on field performance of pinto bean (Phaseolus vulgaris L.) cultivars. African Journal of Agricultural Research. 5: 893-897.

Ghassemi-Golezani, K., SheikhzadehMosaddegh, $\mathrm{P}$ and Valizadeh, $\mathrm{M}$. 2008 b. Effects of hydro-priming duration and limited irrigation on field performance of chickpea. Research Journal of Seed Science. 1: 34-40.

ISTA. 1985. International rules for seed testing. Seed Science and Technology. 13: 299-355.

ISTA. 1999. International rules for seed 
testing. Seed Science and Technology. 27: 25-30.

Jackson, M. L. 1973. Soil chemical analysis. Prentice Hall of India Private Limited, New Delhi

Kawatra and Sehgal, 2007. Value added products of maize. (Quality protein maize and baby corn). National Conference on "Double Maize Production" organized by IFFCO Foundation, ICAR, DMR, DAC \& IFFCL at New Delhi on May 08-09, 2007.

Kundu, C and Basu, R.N. 1981. Hydrationdehydration treatment of stored carrot seed for the maintenance of vigour, viability and productivity. Scientia Horticulture. 15: 117-125.

Mc Donald, M.B. 2000. Seed priming. In M .Black, J.D. Bewley (eds.) - Seed technology and biological basis. Sheffield Academic Press. pp: 156168.

Meena, O. P. 2000. Effect of nitrogen and plant population on performance of maize (Zea mays L.): varieties for green cob Agronomy, Maharana Pratap University of Agriculture and Technology, Udaipur.

Misra, N.M. and D.P. Dwivedi, 1980. Effect of pre- treatments on growth and chemical components on sowing seed treatment on growth and dry matter faba bean plants under saline conditions. Annals of accumulation of high yielding wheat under rain-fed Agricultural Science, 44: 159-171.

Muntz, K., Belozersky, M.A., Dunaevsky, Y.E., Schlereth, A and Tiedemann, J. 2001. Stored proteinases and the initiation of storage protein mobilization in seeds during germination and seedling growth. Journal of Experimental Botany. 52: 1741-1752.

Yarnia M, Tabrizi EFM. Effect of seed priming with different concentration of GA3, IAA and Kinetin on Azarshahr Onion germination and seedling Growth. Journal of Basic and Applied Scientific Research. 2012; 2(3):2657-2661.

\section{How to cite this article:}

Akash Bhargaw, Akanksha, Dnyaneshwar Arjun Madane and Priyamvada Chauhan. 2019. Effect of Halo Priming, Osmo Priming and Hydro Priming on Fresh and Accelerated Aged Seeds of Baby Corn (Zea mays L.) on Germination, Seedling Dry Weight, Seedling Length. Int.J.Curr.Microbiol.App.Sci. 8(05): 1474-1479. doi: https://doi.org/10.20546/ijcmas.2019.805.169 